\title{
INTERNALISASI ASUMSI PEMBELAJARAN ANDRAGOGI PADA MATA KULIAH STATISTIK
}

\author{
Elizon Nainggolan, Silvia Mariah H, Fauzi Kurniawan*) \\ Surel: elizonnaingg06@gmail.com
}

\begin{abstract}
This type of research is a quasi-experimental research with pretest-posttest control group design that aims to determine differences in students' learning ability by using andragogy approach and learning by pedagogy approach. Population in this study all students Department of PLS NIM 2015. Sampling is done randomly after given treatment In each class. Data collected through documentation, test, and observation method. Based on the result of $t$ test on pre-test, it was known that the average value obtained by the students in the experimental group is 75.23, which means higher than the average value in the control group that is 72.50. In t test we got $t_{\text {count }}=-2,688$; Whereas $t_{\text {table, namely }} t_{d f}=29 ; \alpha=0,05=2.04$. This means that $t_{\text {count }}>t_{d f}=29 ; \alpha=0.05$. So the pre-test is quite different although less significant. In the post test, it can be seen that the average value of students in the experimental group is 89.50 higher than the average score of the students in the control group is 77.00. In t test we got statistical value $t_{\text {count }}$ $=-10.012 ;$ Whereas $t_{\text {table, }}$ namely $t_{d f}=29 ; \alpha=0.05=2.04 ;$ Which means that $t_{\text {count }}>t_{d f}=29 ; \alpha$ $=0.05$. So, the two average values are significantly different significantly. Based on the results of statistical tests it is known that: (1) the learning results seen from the average score of student exam results in following the learning by using andragogy approach significantly higher than the students who Follow the learning by using Pedagogical approach, (2) there is improvement of numeracy ability and data processing of student which can be seen from study result and average value in student group that follow learning by using approach of andragogy higher than student group that follow learning by using approach Pedagogy.
\end{abstract}

Kata Kunci: Internalisasi, Andragogi, Pedagogi

\section{PENDAHULUAN}

$\mathrm{T}$

ujuan umum pendidikan nasional yaitu untuk menciptakan manusia dan masyarakat Indonesia yang maju, mandiri, dan sejahtera lahir dan batin. Manusia dan masyarakat yang maju tercermin dari semakin tingginya tingkat pendidikan dalam arti luas (pengetahuan, keterampilan, dan sikap mental), kesehatan dan pendapatan, serta nilai budaya yang berorientasi masa depan.

Seiring dengan kurikulum pendidikan yang terus berevolusi, pendidik tidak perlu lagi hanya berteori kepada peserta didik. Peserta didik perlu diperlakukan sebagai pembelajar yang dapat menyerap pengalaman dari proses pembelajaran yang menarik dan menyenangkan. Oleh karena itu, pembelajaran di

\footnotetext{
*) Drs. Elizon Nainggolan, M.Pd.: Dosen Jurusan PLS FIP UNIMED

Sivia Mariah H, S.Pd., M.Pd. : Dosen Jurusan PLS FIP UNIMED

Fauzi Kurniawan, S.Psi, M.Psi : Dosen Jurusan PLS FIP UNIMED
} 
dalam kelas harus menjadi tempat belajar yang mampu mengubah pola pikir dan menyedot perhatian peserta didik untuk belajar, berpendapat, mengambil inisiatif, atau berinteraksi.

Melalui kegiatan pembelajaran yang inovatif, atmosfer kelas tidak akan menjadi kaku dan monoton. Para peserta didik diajak untuk berdiskusi, berinteraksi, dan berdialog sehingga mereka mampu mengkonstruksikan konsep dan kaidah pengetahuan yang mereka pelajari. Para peserta didik juga dibiasakan untuk berbeda pendapat sehingga mereka menjadi sosok yang cerdas dan kritis

Mahasiswa memiliki peranan yang penting dalam pembangunan masyarakat. salah satunya di bidang pendidikan. Sebagai agent of change, memaksimalkan potensi sumber daya alam di lingkungan sekitar.

\begin{tabular}{llr}
\multicolumn{2}{c}{ Dalam } & melaksanakan \\
penelitian & dan & pemberdayaan \\
masyarakat & dimana & sampelnya
\end{tabular} sebagaian besar adalah warga masyarakat yang merupakan orang dewasa, mahasiswa harus memahami karakteristik orang dewasa dan memahami bagaimana melakukan pendekatan yang tepat dalam berinteraksi dengan orang dewasa. Akan tetapi, tidak semua mahasiswa mampu menerapkan hal tersebut. Berdasarkan pemikiran-pemikiran di atas, penulis tertarik untuk mengadakan penelitian tentang mahasiswa harus mampu membawa sesuatu yang bernilai lebih pada masyarakat, memiliki jiwa kepemimpinan, tanggung jawab, akhlak mulia, dan berbudi pekerti baik. Mahasiswa harus senantiasa berbaur dengan masyarakat dalam proses pembangunan sesuai dengan bidang studi masing-masing dengan mengaplikasikan apa yang telah mereka dapatkan di bangku perkuliahan untuk mendukung proses pembangunan. Sebagai contoh, mahasiswa jurusan pendidikan luar sekolah dapat mengambil peran di masyarakat dalam bidang kepemudaan seperti mengkoordinasikan kegiatan gotong royong di lingkungan tempat tinggal, kegiatan karang taruna, mahasiswa dapat memberikan sumbangsih gagasan-gagasan cemerlang untuk Internalisasi Asumsi Pembelajaran Andragogi dalam Mata Kuliah Statistik pada Mahasiswa PLS.

\section{Rumusan Masalah}

Berdasarkan masalah umum tersebut, maka dapat dirumuskan permasalahan sebagai berikut :

1. Bagaimana internalisasi asumsi pembelajaran andragogi pada mata kuliah statistik .

2. Bagaimana internalisasi asumsi pembelajaran pedagogi pada mata kuliah statistik.

3. Apakah terdapat perbedaan internalisasi asumsi pembelajaran 
andragogi dan pedagogi pada mata kuliah statistik.

\section{TINJAUAN PUSTAKA \\ Pendekatan Pedagogi}

Pedagogi merupakan konsep pembelajaran yang menempatkan murid/siswa sebagai obyek di dalam pendidikan, mereka mesti menerima pendidikan yang sudah disusun oleh sistem pendidikan, di susun oleh guru/pengajar. Apa yang dipelajari, materi yang akan diterima, metode panyampaian, dan lain-lain, semua tergantung kepada pengajar dan tergantung kepada sistem. Murid sebagai obyek dari pendidikan.

Kelemahan yang terdapat dalam pendekatan Pedagogi adalah siswa yang memiliki keunikan, talenta, minat, dan kelebihan menjadi tidak berkembang, tidak bisa mengeksplorasi dirinya sendiri dan tidak mampu menyampaikan kebenarannya sendiri sebab yang memiliki kebenaran adalah masa lalu, sesuatu yang sudah mapan dan sudah ada sampai sekarang. Perbedaan bukanlah menjadi hal biasa, melainkan jika ada yang berbeda itu akan dianggap sebagai sebuah perlawanan dan pemberontakan. Namun Pedagogy masih memiliki kelebihan yakni di dalam menjaga rantai keilmuan yang sudah diawali oleh orang-orang terdahulu, maka rantai emas dan benang merah keilmuan bisa dilanjutkan oleh generasi mendatang.
Generasi mendatang tidak perlu mulai dari nol lagi, melainkan tinggal melanjutkan apa yang sudah ditemukan, apa yang sudah dirintis dan sudah dimulai oleh generasi mendatang.

\section{Pendekatan Andragogi}

Malcolm Knowles dalam publikasi jurnal yang berjudul "The Adult Learner, A Neglected Species" yang diterbitkan pada tahun 1970 mengungkapkan teori belajar yang tepat bagi orang dewasa. Sejak saat itulah istilah "Andragogi" mulai diperbincangkan oleh berbagai kalangan khususnya para ahli pendidikan.

Pendekatan pembelajaran Andragogy dikenal istilah-istilah Enjoy Learning, Workshop, Pelatihan Outbond dll, dan dari konsep Pendidikan Andragogy inilah kemudian muncul konsep-konsep Liberalisme pendidikan, Liberasionisme pendidikan dan Anarkisme pendidikan. Liberalisme pendidikan bertujuan jangka panjang untuk melestarikan dan memperbaiki tatanan sosial yang ada dengan cara mengajar setiap siswa bagaimana cara menghadapi persoalan-persoalan dalam kehidupan sehari-hari secara efektif. Liberasionisme pendidikan adalah sebuah sudut pandang yang menganggap bahwa kita harus segera melakukan perombakan dalam ruang lingkup besar terhadap tatanan politik dan pendidikan yang ada, sebagai 
cara untuk memajukan kebebasankebebasan individu dan mempromosikan perwujudan potensi-potensi diri semaksimal mungkin. Bagi pendidik liberasionis, sekolah bersifat obyektif namun tidak sentral dan sekolah bukan hanya mengajarkan pada siswa bagaimana berpikir yang efektif secara rasional dan ilmiah, melainkan juga mengajak siswa untuk memahami kebijaksanaan tertinggi yang ada di dalam pemecahan-pemecahan masalah secara intelek yang paling meyakinkan. Secara moral, sekolah berkewajiban mengenalkan dan mempromosikan program-program sosial konstruktif dan bukan hanya melatih pikiran siswa. Sekolahpun harus memajukan pola tindakan yang paling meyakinkan didukung oleh sebuah analisis obyektif berdasarkan fakta-fakta yang ada. Hal ini sejalan dengan pendapat Aristoteles tentang prinsip pendidikan yaitu sebagai wahana pengkajian fakta-fakta, mencari 'obyektif', melalui pengamatan atas kenyataan. Anarkisme pendidikan pada umumnya menerima sistem penyelidikan eksperimental yang terbuka (pembuktian pengetahuan melalui penalaran ilmiah). Menurut anarkisme pendidikan, pendekatan terbaik terhadap pendidikan adalah pendekatan yang mengupayakan percepatan perombakan humanistik berskala besar yang mendesak ke dalam masyarakat dengan cara menghapuskan sistem persekolahan konvensional.

\section{Asumsi Pembelajaran Andragogi}

\section{a. Konsep Diri}

Konsep diri seorang anak yang beranjak menuju ke arah dewasa, mereka menjadi berkurang ketergantungannya kepada orang lain. Orang dewasa memerlukan perlakuan yang sifatnya menghargai, khususnya dalam pengambilan keputusan. Orang dewasa akan menolak apabila diperlakukan seperti anak-anak, diberi ceramah apa yang harus dilalukan dan apa yang tidak boleh. Orang dewasa menolak situasi belajar yang kondisinya bertentangan dengan konsep diri mereka sebagai pribadi yang mandiri.

Beberapa implikasi dari asumsi konsep diri di atas diantaranya :

- Iklim belajar diciptakan sesuai dengan keadaan orang dewasa. Baik ruangan dan peralatan (kursi, meja, dan sejenisnya) disusun dan diatur sesuai dengan selera orang dewasa dan memberikan rasa nyaman.

- Peserta diikutsertakan dalam mendiagnosa kebutuhan belajarnya. Mereka akan merasa terlibat dan termotivasi untuk belajar, bila yang akan dipelajari itu sesuai dengan kebutuhan yang ingin dipelajarinya.

- Peserta dilibatkan dalam proses perencanaan belajar. Dalam perencanaan ini kedudukan 
fasilitator lebih banyak berfungsi sebagai pembimbing dan sumber informasi.

- Dalam proses belajar mengajar merupakan tanggung jawab bersama antara fasilitator dan peserta.

- Evaluasi belajar dalam proses belajar secara andragogik menekankan kepada cara evaluasi diri sendiri

b. Pengalaman

$\begin{array}{rrr}\text { Setiap } & \text { orang dewasa } \\ \text { mempunyai } & \text { pengalaman } & \text { yang }\end{array}$
berbeda. Makin lama ia hidup, makin menumpuk pengalaman yang dimiliki dan makin berbeda pula pengalamannya dengan orang lain. Perbedaan pengalaman orang dewasa dan anak menimbulkan konsekuensi dalam belajar. Beberapa implikasi adanya pengalaman orang dewasa dengan anak-anak dalam proses belajar adalah :

- Proses belajar pada orang dewasa lebih ditekankan kepada teknik yang sifatnya menyadap pengalaman mereka seperti kelompok diskusi, metode kasus, simulasi kerja, permainan peran, latihan praktek, metode proyek, bimbingan konsultatif, demonstrasi dan seminar.

- Penekanan dalam proses belajar pada aplikasi praktis. Pengenalan terhadap konsep baru dijelaskan melalui pengalaman hidup yang berasal dari peserta didik sendiri, serta cara mengaplikasikan hasil belajarnya dalam kehidupan sehari-hari.

- Penekakan dalam proses belajar adalah belajar dari pengalaman dan bagaimana belajar dengan menganalisis pengalamannya sendiri.

\section{c. Kesiapan Belajar}

Hasil studi menunjukkan bahwa orang dewasa mempunyai masa kesiapan untuk belajar. Masa ini sebagai akibat dari peranan sosialnya. Robert J Havighurts dalam Arif (1990:12) membagi masa dewasa itu atas 3 fase serta mengidentifikasi 10 peranan sosial dalam masa dewasa yaitu 1) fase dewasa awal umur antara 18-30 tahun, 2) Fase dewasa pertengahan umur antara 30-35 tahun, dan 3) Fase dewasa akhir umur antara 55 tahun keatas. Sedangkan 10 peranan sosial pada masa dewasa adalah sebagai pekerja, kawan, orang tua, kepala rumah tangga, anak dari orang tua yang sudah berumur, warga negara, anggota organisasi, kawan sekerja, anggota keagamaan, dan pemakai waktu luang. Menurut Havighurts, penampilan orang dewasa dalam melaksanakan peranan sosialnya berubah sejalan dengan perubahan ketiga fase masa dewasa itu, sehinggga mengakibatkan perubahan dalam kesiapan belajar. Sebagai implikasi dalam proses belajar orang 
dewasa yang telah diuraiakan di atas, maka :

- Urutan kurikulum dalam proses belajar orang dewasa disusun berdasarkan tugas perkembangannya dan bukan disusun berdasarkan urutan logis mata pelajaran atau berdasarkan kebutuhan kelembagaan.

- Adanya konsep mengenai tugastugas perkembangan pada orang dewasa akan memberikan petunjuk dalam belajar secara kelompok. Belajar secara kelompok yang anggota kelompoknya bersifat homogen akan lebih efektif.

d. Orientasi terhadap Belajar

Dalam belajar antara orang dewasa dengan anak-anak berbeda dalam perspektif waktunya. Anakanak cenderung mempunyai perspektif menumpuk pengetahuan dan menunda aplikasi apa yang dipelajari untuk dapat bermanfaat dalam kehidupannya kelak. Sebaliknya orang dewasa mempunyai perspektif untuk secepatnya mengaplikasikan apa yang telah dipelajari dalam memecahkan masalah yang dihadapi dalam kehidupannya.

Implikasi dalam proses belajar orang dewasa dengan adanya perbedaan dalam orientasi belajar adalah :
- Para pendidik orang dewasa bukanlah berperan sebagai seorang guru yang mengajarkan mata pelajaran tertentu, tetapi

6 berperan sebagai pemberi bantuan kepada orang yang belajar.

- Kurikulum dalam pendidikan dewasa tidak berorientasi kepada mata pelajaran, tetapi berorientasi kepada masalah karena dewasa berorientasi kepada masalah dalam orientasi belajarnya.

\section{Perbedaan Pendekatan \\ Andragogi dan Pedagogi}

Dalam pedagogi atau konvensional, karena berpusat pada materi pembelajaran (Subject Matter Centered Orientation) maka implikasi yang timbul pada umumnya peranan guru, pengajar, pembuat kurikulum, evaluator sangat dominan. Pihak murid atau peserta pelatihan lebih banyak bersifat pasif dan menerima

Hal ini dapat terlihat pada halhal sebagai berikut :

- Penentuan materi pengetahuan dan ketrampilan yang perlu disampaikan bersifat standar dan kaku;

- Penentuan dan pemilihan prosedur, metoda dan teknik yang paling efisien untuk menyampaikan materi pembelajaran 
- Pengembangan rencana dan bentuk urutan/sequence yang standard / kaku

- Adanya standard evaluasi yang baku untuk menilai tingkat pencapaian hasil belajar, bersifat kuantitatif mengukur tingkat pengetahuan;

- Adanya batasan waktu yang ketat dalam menyelesaikan suatu proses pembelajaran materi pengetahuan dan ketrampilan

Sedangkan dalam andragogi, peranan guru, pengajar atau pembimbing yang sering disebut dengan fasilitator adalah mempersiapkan perangkat atau prosedur untuk mendorong dan melibatkan secara aktif seluruh warga belajar, yang dikenal dengan pendekatan partisipatif. dalam proses belajar yang melibatkan elemenelemen:

- Menciptakan iklim dan suasana yang mendukung proses belajar mandiri;

- Menciptakan mekanisme dan prosedur untuk perencanaan bersama dan partisipatif;

- Diagnosis kebutuhan belajar yang spesifik

- Merumuskan tujuan-tujuan program yang memenuhi kebutuhan belajar

- Merencanakan pola pengalaman belajar

- Melakukan dan menggunakan pengalaman belajar ini dengan metoda dan teknik yang memadai
- Mengevaluasi hasil belajar dan mendiagnosis kembali kebutuhan belajar.

Tabel 1. Perbedaan pedagogik dan andargogi sebagai berikut:

\begin{tabular}{|c|c|c|c|}
\hline No & Asumsi & Pedagogik & Andragogi \\
\hline 1 & $\begin{array}{l}\text { Kosep } \\
\text { diri } \\
\text { peserta } \\
\text { didik }\end{array}$ & $\begin{array}{l}\text { Peserta didik } \\
\text { sebagai individu } \\
\text { yang bersifat } \\
\text { Guru } \\
\text { bertanggung } \\
\text { jawab penuh } \\
\text { untuk } \\
\text { menentukan apa } \\
\text { yang harus } \\
\text { dipelajari,cara } \\
\text { dan apa } \\
\text { hasil yang } \\
\text { diharapkan }\end{array}$ & $\begin{array}{l}\text { Peserta didik } \\
\text { menuju proses } \\
\text { pendewasaan } \\
\text { akan berubah } \\
\text { dari bersifat } \\
\text { tergantung } \\
\text { kepada kemampuan } \\
\text { mengarahkan } \\
\text { diri sendiri. } \\
\text { Dan guru } \\
\text { bertanggungja } \\
\text { wab untuk } \\
\text { mengarahkan } \\
\text { memotivasi, } \\
\text { memelihara } \\
\text { kelangsungan } \\
\text { perubahan }\end{array}$ \\
\hline 2 & $\begin{array}{l}\text { Penga } \\
\text { laman } \\
\text { peserta } \\
\text { didik }\end{array}$ & $\begin{array}{l}\text { Pengalaman } \\
\text { yang dimiliki } \\
\text { peserta didik } \\
\text { tidak besar } \\
\text { nilainya, namun } \\
\text { pengalaman } \\
\text { lebih banyak } \\
\text { yang diperoleh } \\
\text { dari guru dan } \\
\text { para ahli } \\
\text { sehingga teknik } \\
\text { penyampaian } \\
\text { berupa: } \\
\text { ceramah, tugas } \\
\text { baca, dan } \\
\text { penyajian } \\
\text { melalui visual }\end{array}$ & $\begin{array}{l}\text { Seseorang } \\
\text { akan } \\
\text { menangkap } \\
\text { arti dengan } \\
\text { lebih baik } \\
\text { tentang apa } \\
\text { yang dialami } \\
\text { daripada } \\
\text { memperoleh } \\
\text { secara pasif, } \\
\text { oleh karena itu } \\
\text { teknik } \\
\text { penyampaian } \\
\text { yang utama } \\
\text { adalah } \\
\text { eksperimen, } \\
\text { percobaan di } \\
\text { laboratorium, } \\
\text { diskusi, } \\
\text { pemecahan } \\
\text { masalah, } \\
\text { latihan } \\
\text { simulasi, dan } \\
\text { praktek } \\
\text { lapangan. }\end{array}$ \\
\hline 3 & $\begin{array}{l}\text { Kesiapan } \\
\text { belajar }\end{array}$ & $\begin{array}{l}\text { Seseorang harus } \\
\text { siap } \\
\text { mempelajari } \\
\text { apapun yang } \\
\text { diberikan guru, } \\
\text { dan hal ini } \\
\text { menimbul kan } \\
\text { tekanan yang } \\
\text { cukup besar } \\
\text { karena adanya }\end{array}$ & $\begin{array}{l}\text { Seseorang } \\
\text { akan siap } \\
\text { mempelajari } \\
\text { sesuatu bila ia } \\
\text { merasa perlu } \\
\text { melakukannya } \\
\text { untuk dapat } \\
\text { memecahkan } \\
\text { masalah atau } \\
\text { menyelesaikan }\end{array}$ \\
\hline
\end{tabular}




\begin{tabular}{|c|c|c|c|}
\hline & & $\begin{array}{l}\text { perasaan takut } \\
\text { gagal, anak } \\
\text { yang sebaya } \\
\text { diaggap siap } \\
\text { untuk } \\
\text { mempelajari hal } \\
\text { yang sama pula, } \\
\text { oleh karena itu } \\
\text { kegiatan belajar } \\
\text { harus diorganisa } \\
\text { sikan dalam } \\
\text { kurikulum yang } \\
\text { baku, dan } \\
\text { langkah } \\
\text { penyajian harus } \\
\text { sama bagi } \\
\text { semua orang. }\end{array}$ & $\begin{array}{l}\text { tugas sehari- } \\
\text { hari dengan } \\
\text { baik. Fungsi } \\
\text { pendidik } \\
\text { menciptakan } \\
\text { kondisi, } \\
\text { menyiapkan } \\
\text { alat serta } \\
\text { prosedur untuk } \\
\text { membantu } \\
\text { menemukan } \\
\text { yang perlu di } \\
\text { ketahui. }\end{array}$ \\
\hline 4 & $\begin{array}{l}\text { Orienta } \\
\text { si } \\
\text { belajar }\end{array}$ & $\begin{array}{l}\text { Peserta didik } \\
\text { menyadari } \\
\text { bahwa } \\
\text { pendidikan } \\
\text { suatu proses } \\
\text { penyampaian } \\
\text { ilmu pengetahu } \\
\text { an yang akan } \\
\text { bermanfaat di } \\
\text { kemudian hari } \\
\text { sehingga } \\
\text { kurikulum } \\
\text { disusun sesuai } \\
\text { dengan unit } \\
\text { mata pelajaran } \\
\text { dan mengikuti } \\
\text { urutan logis } \\
\text { ilmunya }\end{array}$ & $\begin{array}{l}\text { Peserta didik } \\
\text { menyadari } \\
\text { bahwa } \\
\text { pendidikan } \\
\text { merupakan } \\
\text { proses } \\
\text { peningkatan } \\
\text { kemampuan } \\
\text { diri untuk } \\
\text { mengembang } \\
\text { kan potensi dan } \\
\text { keterampilan } \\
\text { yang maksimal } \\
\text { untuk mencapai } \\
\text { kehidupan yang } \\
\text { lebih baik atau } \\
\text { lebih efektif }\end{array}$ \\
\hline
\end{tabular}

\section{Kerangka Konseptual}

Dengan menggunakan pendekatan andragogi diharapkan akan lebih efektif dan mampu meningkatkan kemampuan mahasiswa dalam membuat instrumen penelitian. Internalisasi andragogi mengarah pada 4 aspek yaitu mengidentifikasi, menggeneralisasi, menganalisis, serta mengklarifikasi. Selain dalam mata kuliah tersebut, mahasiswa juga diharapkan memiliki kemampuan memecahkan masalah karena pemecahan masalah merupakan kompetensi yang sangat penting dalam pembelajaran PLS. Langkahlangkah dalam pemecahan masalah yaitu memahami masalah, perencanaan penyelesaian masalah, menyelesaikan masalah, dan memeriksa kembali hasil yang diperoleh.

Pembelajaran didesain sedemikian rupa agar mahasiswa mampu mengkonstruk pengetahuan dalam pemikirannya, mencatat pola berpikir sendiri, dan mengalami sendiri perolehan pengalaman pembelajaran.

Di sisi lain, pada pembelajaran pedagogi pembelajaran hanya merupakan proses pentransferan pengetahuan dan mahasiswa cenderung meniru dalam pembelajaran. Mahasiswa jarang sekali mengkonstruksi pengetahuannya sendiri dan gagal menerapkan pengetahuan tersebut ketika dituntut untuk menyelesaikan suatu permasalahan. Dari uraian di atas, diduga terdapat perbedaan internalisasi andragogi pada mahasiswa dengan menggunakan pendekatan andragogi dan pendekatan pedagogi.

\section{HASIL PENELITIAN Pelaksanaan Pre-Test}

Pelaksanaan

pre-test dilakukan terhadap kedua kelompok perlakuan dengan jenis soal yang sama. Soal pre-test ini berbentuk tes tertulis pilihan ganda dengan empat opsi. Jumlah soal sebanyak 25 butir 
dengan durasi waktu mengerjakan 50 menit (1 SKS). Bobot untuk setiap butir soal sama yaitu 4 (empat). Jadi, nilai maksimum yang didapatkan siswa adalah 100. Kemudian hasil pre-test tersebut diperiksa dan berdasarkan hasil pemeriksaan tersebut yang dicari : nilai terendah, nilai tertinggi, dan nilai rata-rata. Kemudian, dengan menggunakan nilai rata-rata tersebut dilakukan uji perbedaan nilai rata-rata untuk mendapatkan kepastian perbedaan antara kelas pembanding (control) dan kelas perlakuan (eksperimen).

\section{Pelaksanaan Pembelajaran}

Setelah dilakukan pre-test, kemudian dilakukan proses pembelajaran dengan materi Konsep Dasar Statistik dan Perhitungan Dasar Statistik. Pembelajaran pada kelompok perlakuan menggunakan pendekatan Andragogi; sementara pembelajaran pada kelompok pembanding hanya menggunakan pendekatan Pedagogi. Durasi waktu pembelajaran untuk kedua kelompok sama, yaitu 8 kali 50 menit untuk materi Konsep Dasar Statistik dan materi Perhitungan Dasar Statistik. Hal yang dapat dicermati dalam tahapan ini yaitu bahwa mahasiswa pada kelas eksperimen lebih antusias terhadap materi pembelajaran dibandingkan dengan mahasiswa pada kelas kontrol.

\section{Pelaksanaan Post-Test}

Sama halnya seperti pada pretest, post-test pada penelitian ini juga dilakukan terhadap dua kelompok perlakuan dengan materi, jumlah, dan opsi pertanyaan yang sama. Pertanyaan pada instrumen post-test juga berupa tes tertulis dengan 4 opsi pilihan ganda. Jumlah pertanyaan yang diberikan juga sama yaitu sebanyak 25 butir dengan durasi 50 menit, dengan bobot untuk setiap butir pertanyaan sama yaitu 4 (empat). Jadi, nilai maksimum yang dapat diperoleh mahasiswa yaitu 100 . Hasil post-test kemudian diperiksa dan dilakukan perbandingan: nilai terendah, nilai tertinggi, dan nilai rata-rata. Untuk nilai rata-rata kemudian dilakukan uji hipotesis untuk penarikan kesimpulan apakah pendekatan pedagogi dapat meningkatkan kemampuan berhitung mahasiswa pada mata kuliah Statistik.

\section{Analisis Hasil Pre-Test}

Pre-test dilakukan untuk mengetahui kompetensi awal yang dimiliki peserta didik berkaitan dengan topik Konsep Dasar Statistik dan Perhitungan Dasar Statistik. Selain itu, pre-test dalam penelitian ini dilakukan untuk mendapatkan informasi bahwa mahasiswa pada kedua kelompok kontrol dan eksperimen memiliki kompetensi yang tidak jauh berbeda untuk materi tersebut. Rangkuman hasil analisis 
terhadap nilai pre-test disajikan tabel berikut.

Tabel 3. Descriptive Statistics Pre- Tabel 6. Descriphiestatistiss

\begin{tabular}{|c|c|c|c|c|c|c|c|c|c|c|}
\hline & $\mathbb{N}$ & |rimin| & Ilemun & |lean & 9H:Deision & bariocer & \multicolumn{2}{|c|}{ Sleness } & \multicolumn{2}{|c|}{ Kuntosis } \\
\hline & Selisic & Setesicic & Solstic & Sábicic & Sabisic & Selisic & Sebisic & Suldorol & Setasicic & SWEETOO \\
\hline Kantol & 3) & on & 85 & 1250 & 6280 & 39224 & .156 & 427 & N14 & 839 \\
\hline Elspermen & 3) & o. & $D$ & 15.23 & 4883 & 23357 & 1339 & 427 & 2338 & 898 \\
\hline Valin ||isuiset) & 30 & & & & & & & & & \\
\hline
\end{tabular}

Pada tabel di atas dapat dilihat bahwa pada saat pre-test, nilai minimum yang diperoleh untuk kelas kontrol dan kelas eksperimen yaitu 60 , sedangkan nilai maksimum untuk kelas kontrol 85 dan eksperimen 80. Nilai mean untuk kelas kontol sebesar 72,50 dengan nilai statistik standar deviasi sebesar 6,26, sedangkan untuk kelas eksperimen nilai mean yang diperoleh sebesar 75,23 dengan nilai statistik standar deviasi sebesar 4,83.

Tabel 4. Paired Samples Statistics Pre-Test

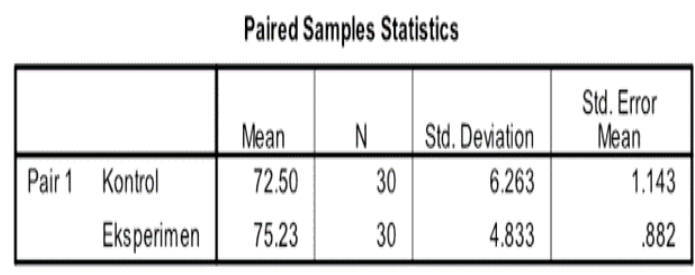

Tabel 5. Paired Samples

Correlations Pre-Test

Paired Samples Correlations

\begin{tabular}{|l|l|r|c|}
\hline & N & Correlation & Sig. \\
\hline 10 Kontrol \& Eksperimen & 30 & 521 & 003 \\
\hline
\end{tabular}

Paired Samples Test for Pre-Test

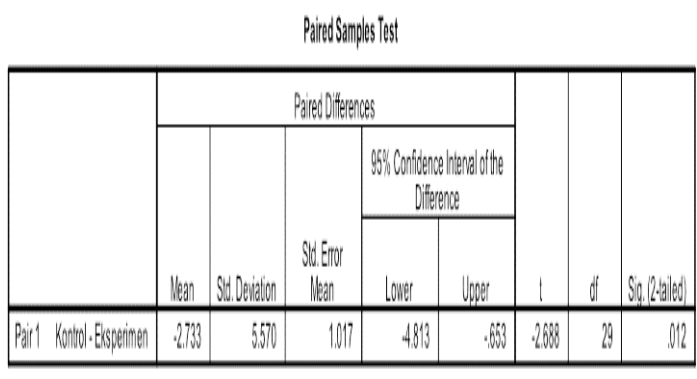

Berdasarkan hasil analisis di atas, dapat dilihat bahwa nilai ratarata yang diperoleh mahasiswa pada kelompok eksperimen yaitu 75,23, yang berarti lebih tinggi daripada nilai rata-rata pada kelompok kontrol yaitu 72,50. Pada perhitungan Uji t didapatkan nilai statistik $\mathrm{t}_{\text {Hitung }}=$ 2,688; sedangkan $\mathrm{t}_{\text {Tabel, }}$, yaitu $\mathrm{t}_{\mathrm{df}=29}$; $\propto=0,05=2,04$. Hal ini berarti bahwa $t_{\text {Hitung }}>\quad t_{\mathrm{df}=29 ; \quad} \propto=0,05 . \quad$ Dengan demikian, dapat ditarik kesimpulan bahwa berdasarkan hasil perhitungan statistik kedua nilai rata-rata tersebut memiliki perbedaan. Artinya bahwa kompetensi mahasiswa dalam topik Konsep Dasar Statistik dan Perhitungan Dasar Statistik pada kedua kelompok tersebut cukup berbeda.

\section{Analisis Hasil Post-Test}

Setelah dilaksanakannya proses pembelajaran terhadap kedua kelompok dilakukan ujian tengah semester sekaligus post-test dalam penelitian. Ujian tengah semester dan post-test dilakukan dengan tujuan, (1) untuk mengukur kompetensi mahasiswa dalam materi Konsep p-ISSN : 1693 - 1157, e-ISSN : 2527 - 9041 
Dasar Statistik dan Perhitungan Statistik Dasar setelah mahasiswa menyelesaikan proses pembelajaran; (2) untuk membandingkan hasil belajar mahasiswa setelah mengikuti proses pembelajaran Andragogi.
Kemudian, setelah pelaksanaan posttest dilakukan analisis terhadap hasil post-test. Berikut ini disajikan rangkuman hasil analisis nilai posttest mahasiswa.

Tabel 7. Descriptive Statistics

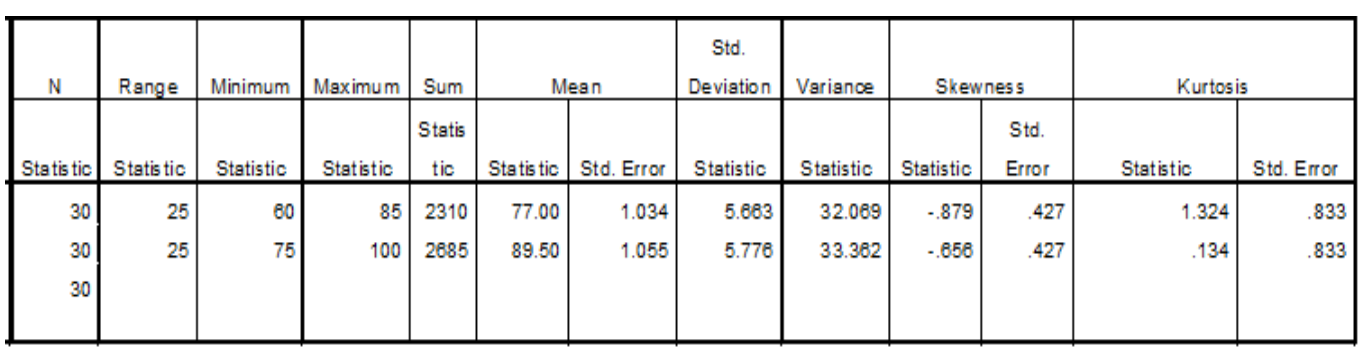

Pada tabel di atas dapat dilihat bahwa berdasarkan hasil posttest, nilai minimum untuk kelas kontrol dan kelas eksperimen masing-masing sebesar 60 dan 75, kemudian nilai maksimum yang diperoleh kedua kelompok masingmasing 85 dan 100. Nilai rata-rata yang diperoleh untuk kelas kontrol yaitu 77,00 dan untuk kelas eksperimen yaitu 89,50 dengan nilai statistik standar deviasi masingmasing 5,66 dan 5,77. Hal ini menunjukkan bahwa pendekatan andragogi untuk pembelajaran dengan materi Konsep Dasar Statistik dan Perhitungan Statistik Dasar dapat meningkatkan kemampuan pengolahan datas statistik mahasiswa.
Tabel 8. Paired Samples Statistics

\begin{tabular}{|ll|r|r|r|r|}
\hline & \multicolumn{1}{|c|}{ Mean } & \multicolumn{1}{|c|}{$\mathrm{N}$} & Std. Deviation & Std. Error Mean \\
\hline Pair1 & Kontrol & 77.00 & 30 & 5.663 & 1.034 \\
& Eksperimen & 89.50 & 30 & 5.776 & 1.055 \\
\hline
\end{tabular}

Tabel 9. Paired Samples Correlations
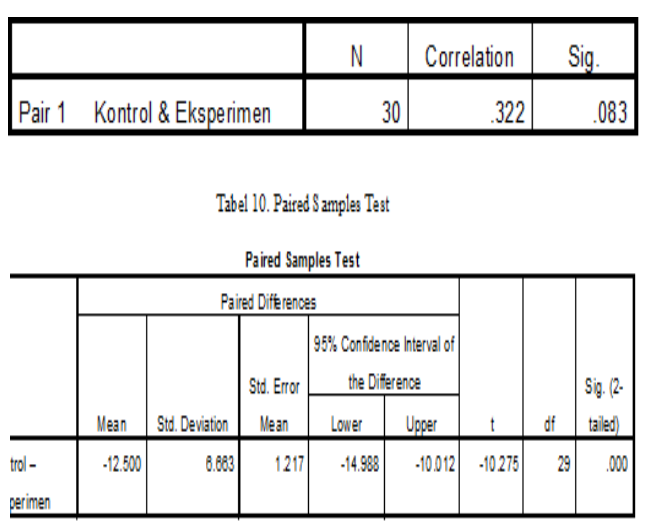

Dari tabel di atas juga dapat dilihat bahwa nilai rata-rata yang diperoleh mahasiswa pada kelompok eksperimen lebih tinggi jika dibandingkan dengan nilai rata-rata yang diperoleh mahasiswa pada kelompok kontrol. Pada perhitungan 
Uji t didapatkan nilai statistik $\mathrm{t}_{\mathrm{Hitung}}=$ -10.01; sedangkan $\mathrm{t}_{\mathrm{Tabel}}$, yaitu $\mathrm{t}_{\mathrm{df}=29}$; $\alpha=0,05=2,698$. Hal ini berarti bahwa $t_{\text {Hitung }}>\mathrm{t}_{\mathrm{df}=29 ; \quad} \quad \propto=0,05 . \quad$ Dengan demikian, dapat dikatakan bahwa secara statistik kedua nilai rata-rata tersebut adalah berbeda nyata. Hal ini berarti, pada post-test, nilai rata-rata yang diperoleh mahasiswa pada kelompok eksperimen lebih tinggi dari nilai rata-rata yang diperoleh mahasiswa pada kelompok kontrol.

Oleh karena itu, dapat dikemukakan bahwa selain dapat meningkatkan kemampuan pengolahan data statistik, pendekatan Andragogi pada materi Konsep Dasar Statistik dan Proses Menghitung Data Statisik juga mampu membantu mahasiswa memperoleh nilai ratarata hasil belajar yang lebih tinggi daripada nilai rata-rata hasil belajar mahasiswa yang dalam proses pembelajarannya menggunakan pendekatan Pedagogi.

\section{PEMBAHASAN PENELITIAN}

HASIL

Selanjutnya

untuk pembahasan lebih lanjut, selain membandingkan hasil post-test pada kedua kelompok, juga dilakukan perbandingan hasil pre-test dan posttest pada masing-masing kelompok. Hasil perhitungan perbandingan kedua tes untuk masing-masing kelompok dapat dilihat pada lampiran. Rangkuman hasil perhitungan tersebut disajikan pada tabel berikut ini.

Tabel 11. Rangkuman Hasil Analisis terhadap Nilai Pre-Test dan Post-Test Kelompok Kontrol

\begin{tabular}{|l|c|c|}
\hline \multicolumn{1}{|c|}{ Ukuran } & Pre-Test & Post-Test \\
\hline Jumlah & 30 & 30 \\
mahasiswa & 60 & 60 \\
Nilai Terendah & 85 & 80 \\
Nilai Tertinggi & 72,5 & 75,23 \\
Nilai Rata-rata & \\
\hline
\end{tabular}

Setelah mengikuti pembelajaran, nilai rata-rata mahasiswa pada kedua kelompok pada materi Konsep Dasar Statistik dan Proses Menghitung Data Statisik mengalami peningkatan. Sebagaimana dapat dilihat pada tabel diatas, kemampuan mahasiswa pada kelompok eksperimen naik dari 72,5 pada saat pre-test meningkat menjadi 75,23 pada saat post-test.

Tabel 12 . Rangkuman Hasil Analisis terhadap Nilai Pre-Test dan Post-Test Kelompok Eksperimen

\begin{tabular}{|c|c|c|}
\hline Ukuran & Pre-Test & Post-Test \\
\hline Jumlah Siswa & 30 & 30 \\
Nilai Terendah & 60 & 75 \\
Nilai Tertinggi & 80 & 100 \\
Nilai Rata-rata & 79,4 & 89,8 \\
\hline
\end{tabular}

Berdasarkan tabel di atas, nilai rata-rata yang diperoleh mahasiswa setelah mengikuti pembelajaran andragogi mengalami p-ISSN : 1693 - 1157, e-ISSN : 2527 - 9041 
kenaikan. Nilai rata-rata yang diperoleh mahasiswa pada kelompok eksperimen meningkat dari 77,00 pada saat pre-test menjadi 89,5 pada saat post-test. Berdasarkan hasil uji statistik, perbedaan nilai rata-rata pre-test dan post-test yang terjadi pada kedua kelompok mahasiswa dapat dikatakan nyata atau signifikan. Hal ini berarti bahwa pembelajaran pada kedua kelompok mahasiswa mengalami peningkatan kemampuan pengolahan data statistik dan peningkatan nilai rata-rata yang diperoleh mahasiswa sehingga dapat dikemukakan bahwa peningkatan kemampuan pengolahan data statisik dan nilai rata-rata hasil pembelajaran dengan pendekatan Andragogi lebih tinggi dibandingkan dengan hasil pembelajaran dengan pendekatan Pedagogi.

Pembelajaran dengan pendekatan Andragogi dilihat dari interaksi antara guru dan peserta didik. Pada prakteknya biasanya selalu guru yang memutuskan apa yang dibutuhkan peserta didik dan bagaimana pengetahuan dan keterampilan harus diajarkan. Menurut Knowles (1970) andragogi memberikan banyak pendekatan yang berguna untuk meningkatkan metodologi pendidikan dan telah diterima secara universal, hal ini masih memiliki korelasi dengan hubungan antara guru dan peserta didik. Pesatnya perubahan kebutuhan pendidikan dalam masyarakat dan ledakan informasi yang diterima melalui teknologi, menunjukkan bahwa sekarang dibutuhkan suatu pendekatan pendidikan dimana peserta didik itu sendiri yang menentukan apa dan bagaimana pembelajaran harus dilakukan.

Andragogi adalah suatu studi yang melibatkan peserta didik dewasa kedalam struktur pengalaman belajar. Dalam hal ini Andragogi memiliki 4 (empat) prinsip yaitu 1) orang dewasa perlu dilibatkan dalam perencanaan dan evaluasi dari pembelajaran yang mereka ikuti, 2) pengalaman (termasuk pengalaman berbuat salah) menjadi dasar untuk aktivitas belajar; 3) orang dewasa paling berminat pada pokok bahasan belajar yang mempunyai relevansi langsung dengan pekerjaannya atau kehidupan pribadinya; 4) belajar bagi orang dewasa lebih berpusat pada permasalahan dibanding pada isinya.

\section{SIMPULAN}

Berdasarkan hasil observasi dan test selama penelitian, temuan pada pelaksanaan pembelajaran, dan analisis terhadap kemampuan berhitung dan mengolah data statistik mahasiswa sebelum dan sesudah pembelajaran Andragogi untuk materi konsep dasar statistik dan menghitung / pengolahan data statisik dapat diambil kesimpulan sebagai berikut: 
1. Kemampuan mahasiswa menguasai materi dasar statistik dan menghitung/pengolahan dots statisik sebelum pembelaj; 13 cukup berbeda

2. Kemampuan mahasiswa menguasai materi dasar statistik dan menghitung / pengolahan data statisik setelah pembelajaran secara signifikan berbeda

3. Antusiasme dan kesungguhan mahasiswa di dalam kelas ketika mengikuti pembelajaran dengan menggunakan pendekatan Andragogi lebih tinggi dibandingkan dengan mahasiswa yang mengikuti pembelajaran pendekatan Paedagogi.

4. Hasil belajar yang dilihat dari nilai rata-rata hasil ujian mahasiswa dalam mengikuti pembelajaran dengan menggunakan pendekatan Andragogi secara signifikan lebih tinggi dibandingkan dengan mahasiswa yang mengikuti pembelajaran dengan menggunakan pendekatan Paedagogi.

Terjadi peningkatan kemampuan berhitung mahasiswa yang dapat dilihat dari hasil belajar dan nilai rata-rata pada kelompok mahasiswa yang mengikuti pembelajaran dengan menggunakan pendekatan Andragogi lebih tinggi dibandingkan dengan kelompok mahasiswa yang mengikuti pembelajaran dengan menggunakan pendekatan Paedagogi.

\section{DAFTAR PUSTAKA}

Arif, Zainuddin. 1990. Andragogi. Bandung : Angkasa.

Lunandi, A.G. 1989. Pendidikan Orang Dewasa Sebuah Uraian Praktis untuk Pembimbing, Penatar, Pelatih, dan Penyuluh Lapangan, Jakarta: PT. Gramedia.

Suryaman. 2000. Model Pembelajaran DPP Melalui Pelajaran dalam Pengelolaan Usaha Kecil : Studi Kasus di PKBM Nurul Hikmah Kabupaten Garut, (Online), (http://digilib.ipu.eddu/pascal availableletd-091210609526/, diakses 12 Mei 2007).

Burhan Nurgiyantoro Gunawan. (2002). Statistik Terapan untuk Penelitian Ilmu-ilmu Sosial. Yogyakarta: Gajah Mada Uniersiti Press.

Hake, R.R. (1999). Analyzing Change/Gain Score. Woodland Hills: Dept of Physics, Indiana University. [Online]. http://www/physics.indiana.du/ sdi/ Analyzing Change-Gain.pdf [3 Januari 2011].

Hase, S. and Kenyon, C. (2000). From andragogy to heutagogy. Ultibase, RMIT. http://ultibase.rmit.edu.au/Articl es/dec00/hase2.htm 
Sudarwan Danim.(2010). Pedagogi,

Andragogi, dan Heutagogi.

Bandung : Alfabeta. 